Article

\title{
Effects of Water Stress on Gas Exchange, Water Relations and Leaf Structure in Two Ornamental Shrubs in the Mediterranean Area
}

\author{
Alessandro Tribulato ${ }^{1}$, Stefania Toscano ${ }^{1, * \mathbb{D}}$, Virginia Di Lorenzo ${ }^{1}$ and Daniela Romano ${ }^{1,2}$ (D) \\ 1 Department of Agriculture, Food and Environment, Università degli Studi di Catania, Via Valdisavoia 5, \\ 95123 Catania, Italy \\ 2 CNR - Trees and Timber Institute (IVALSA), via P. Gaifami 18, 95126 Catania, Italy \\ * Correspondence: stefania.toscano@unict.it; Tel.: +39-0954-7833-03
}

Received: 29 May 2019; Accepted: 14 July 2019; Published: 16 July 2019

\begin{abstract}
One of the main problems in the Mediterranean area is the long dry season, and hence there is a need to individuate plants that are tolerant to low water availability. The mechanisms adopted by different plant species to overcome drought stress conditions and reduce water loss could allow the identification of tolerant species to drought stress, thereby increasing the sustainability of ornamental plant utilization in green areas. In this regard, the aim of this study was to investigate the morphological, physiological, and anatomical responses of Polygala myrtifolia L. and Viburnum tinus L. 'Lucidum' irrigated under different irrigation deficits. In pot plants, four water regimes were adopted $(10 \%, 20 \%, 30 \%$ and $40 \%$ of water container capacity (WC)). Drought stress significantly reduced the biomass accumulation in both shrubs. In Viburnum, total dry biomass reduction was observed only in $10 \%$ WC with a reduction by $33 \%$, while in Polygala, this was observed both in $20 \%$ WC and $10 \%$ WC ( 48\%). The higher deficit irrigation conditions improve the root-to-shoot ratio, which was increased in Polygala 20\% WC (by 20\%) but not in Viburnum ones. The latter species shows higher drought tolerance, as demonstrated by the gas exchange values, chlorophyll fluorescence, leaf structure, and water relationship.
\end{abstract}

Keywords: Polygala myrtifolia L.; Viburnum tinus L. 'Lucidum'; leaf anatomy; chlorophyll a fluorescence; leaf water content; water use efficiency

\section{Introduction}

The use of ornamental plants to develop green areas can be a response to some problems linked to urbanization (i.e., pollution, heat island, etc.), but their use traditionally needs a large amount of water for irrigation. To realize an environmentally friendly landscape, it is necessary to save water, partly by making suitable plant choices.

In the Mediterranean regions, water deficit is one of the main problems for ornamental plant use, and global changes will predictably amplify the present issues, especially in urban areas [1]. In this context, identifying plants that are tolerant to water shortages has attracted considerable interest.

The lack of water is a great problem in the Mediterranean region, characterized by warm summers with little rainfall and, as a consequence, long periods of water unavailability [2], which leads to water stress in plant species. Over time, drought stress, which is frequent in Mediterranean areas, selects species which are particularly suitable to overcoming water deficit [3]; the selective pressure of the Mediterranean climate has modified the plant traits of different regions leading to vegetation communities dominated by sclerophyllous, evergreen shrubs [4].

Traditionally, for ornamental purposes, exotic species have been adopted in Mediterranean gardening, while over recent years, research has been focused on the study of the response of 
Mediterranean native shrub species to water stress [5], also allowing the identification of new ornamentals suitable for sustainable landscaping. The ability of Mediterranean shrubs to tolerate severe drought conditions, one of the main factors affecting plant survival and species distribution, increases their use in the revegetation of semiarid areas [6].

Different species growing in Mediterranean areas could provide good candidates for ornamental plants regarding their tolerance to water shortages. Drought stress harms aesthetic aspects and consequently affects ornamental plant quality. The latter in fact mainly depends on visual appearance, identified as leaf size and color, flower characteristics, number and longevity [7]. Drought stress can also dramatically reduce plant survival after transplantation with high economic losses and impacts on the aesthetic quality of green areas [8].

The successful establishment of ornamental green areas in Mediterranean regions can be achieved through the adequate selection of plant species characterized by a high tolerance to water stress [9]. Tolerant plants are those plants that have the ability to modify their metabolism to guarantee vital and essential physiological processes with a limited amount of water [10]; most of them are Mediterranean-native species.

Drought-tolerant plants are able to modify, during water stress conditions, their morphology and to activate physiological and biochemical processes able to cope with water deficit $[11,12]$. The morphological modifications linked to drought stress reduce shoot and leaf growth, although the modality and the intensity of these phenomena depend on the genotypes, even within the same species [12]. Previous results showed that in Lantana camara L., the differences in total leaf area are linked to the leaf number, while in Ligustrum lucidum W.T. Aiton, they are related only to the leaf sizes [13]. With the avoidance mechanisms to limit water losses, plants reduce the canopy area and hence increase their root/shoot ratio. The response to drought stress also involves anatomical changes: in severe drought stress conditions, Lantana plants increased their spongy tissue [13] to facilitate $\mathrm{CO}_{2}$ diffusion, enhancing the competition among cells for $\mathrm{CO}_{2}$ and light [14].

The reduction of the specific leaf area results in an increasing of the water use efficiency (WUE) [12]; the higher content of chlorophylls and proteins in thicker leaves, the greater photosynthetic capacities per unit leaf area [15].

Water stress, indeed, reduces plant growth and development by decreasing respiration, growth, photosynthesis, assimilate partitioning, moisture, and nutrient relationships [16-18].

Water shortage typically increases stomatal closure in plants, hence reducing gas exchanges and decreasing photosynthetic activity [19]; in some species water unavailability determines smaller stomata formation, able to have faster dynamic characteristics [20]. Under severe drought stress conditions, the decrease of photosynthetic activity often results in plant death [21]. Stomatal closure reduces water loss and also nutrient uptake; therefore, the metabolic pathways are altered and growth is reduced. Some Mediterranean plants, such as Pistacia lentiscus L., when subjected to drought stress, are able to limit water losses through an efficient transpiration control [10].

The efficiency of the PSII photosystem and indirectly the physiological state of the plants can be measured through the measurement of chlorophyll $a$ fluorescence and in particular of the Fv/Fm ratio [22]. According to different studies, with values between 0.78 and 0.85 , the plant is not stressed [23]; values below 0.78 indicate damage to the PSII photosystem [22].

The analysis of the mechanisms adopted by different species to overcome drought stress and reduce water loss could allow the identification of the most tolerant species to be used in arid and semi-arid environments, thus increasing the sustainability of ornamental plant maintenance.

In this context, the purpose of this study was to investigate morphological, physiological, and anatomical responses in Polygala myrtifolia L. and Viburnum tinus L. 'Lucidum' irrigated at different irrigation deficits.

Polygala myrtifolia L., the common name of which is Milkwort, is an erect, much-branched evergreen shrub, of 1-2.5 m in height, with glossy green leaves, native to South Africa [24]. Due to its attractive shape and prolonged blooming, from spring to autumn, the plant is widely used as a pot 
plant and in gardens in regions with a mild climate, because it is sensitive to temperatures below $5{ }^{\circ} \mathrm{C}$. The species is considered to be drought tolerant [25].

Viburnum tinus L., the common name of which Laurustinus, is a typical Mediterranean species [26]. Within this species, the cultivar 'Lucidum', characterized by wider and bright leaves, is quite spread in ornamental green areas. Although for some authors it is a different species (Viburnum. lucidum Mill.) or a botanical variety (Viburnum. tinus var. lucidum (Mill.) Aiton), according to The Plant List website (http://www.theplantlist.org/), it seems that both terms are referred to Viburnum. tinus L. 'Lucidum'. It is a much-branched evergreen shrub that is $3.5 \mathrm{~m}$ in height, with a rounded form and a very dense habitat. The leaves are from narrow-ovate to ovate oblong, shiny dark green; flowering occurs during the winter [24]. It is a Mediterranean sclerophyllous plant with a broad distribution range [27]. The species is considered as a low water-use plant [28,29] and is able to grow in regions with mild winters [30].

Both species are widespread in the Mediterranean area of Italy, in gardens and green areas, because of their ornamental value and adaptability to many environmental conditions. Different studies were carried out on Viburnum to investigate on salt stress response [28,31], but little information is available in terms of growth parameters, photosynthetic efficiency, leaf functional anatomical traits in drought stress conditions.

These two species were chosen on the basis of our previous studies [32]; Polygala myrtifolia L. and Viburnum tinus L. 'Lucidum' were found, respectively, to be moderately sensitive and sensitive to salinity. Since salinity and drought stresses share important adaptation strategies, this work was carried out to verify if unavailability of water activates the same adaptation strategy observed under salinity stress. Unfortunately, in Mediterranean areas, drought is associated with salinity, especially in the coastal areas. If the strategies adopted by plants are the same or similar, it is possible individuate genotypes able to cope together water and salt stress thus improving the compatibility of green areas to Mediterranean environments.

\section{Materials and Methods}

\subsection{Experimental Conditions and Plant Materials}

The experiment was carried out on two ornamental shrubs, Polygala myrtifolia L. and Viburnum tinus L. 'Lucidum', grown in a cold greenhouse in Catania (South Italy, 37 30' N 1506' E; $20 \mathrm{~m}$ above sea level (m.a.s.l.)). Three-month-old rooted cuttings of both species were transplanted into $2.7 \mathrm{~L}$ pots (one plant per pot), filled with sand, silt and clay $(75 \%, 18 \%$ and $7 \%$, respectively), and fertilized with $2 \mathrm{~g} \mathrm{~L}^{-1}$ of Osmocote Plus (14/13/13, N, P, K + microelements). The substrate contained $120.0 \mathrm{~g} / \mathrm{kg}$ organic matter, $102.7 \mathrm{mg} / \mathrm{kg}$ hydrolyzed nitrogen, $116 \mathrm{mg} / \mathrm{kg}$ available $\mathrm{P}$ and $359 \mathrm{mg} / \mathrm{kg}$ available $\mathrm{K}$. The substrates had a $\mathrm{pH}$ of 5.9 and $\mathrm{EC}$ of $2.2 \mathrm{dS} / \mathrm{m}$.

At the beginning of the experiment, the dry biomass of the plants was on average $53.7 \pm 2.3 \mathrm{~g}$ and $109.5 \pm 10.2 \mathrm{~g}$ for Polygala. myrtifolia L. and Viburnum. tinus L. 'Lucidum', respectively.

Three replicates of 12 plants per treatment (144 plants in total per species) were adopted.

\subsection{Substrate Moisture Measurements and Water Supply}

To determine the volumetric content of water in the substrate, an automated management system with dielectric sensors EC 5TE (Decagon Devices Inc., Pullman, WA) was used. Two sensors were used for each treatment and data were recorded using a data acquisition system (data logger) CR1000 (Campbell Scientific Ltd., Loughborough, UK).

Sensors were calibrated following the Starr and Paltineanu [33] protocol, with slight modifications, where a series of each measurements is taken in connection with samples of volumetric soil to quantify the relationship between the substrate (measured with the 5TM) and the volumetric water content (WC). The sensors were installed $10 \mathrm{~cm}$ below the substrate surface at the center of each sample pot. Measurements were regularly taken during the experiment, every $5 \mathrm{~min}$, from 10 July to 20 October. 
The use of the probes was preceded by their calibration to determine the real content of water in the substrate samples, which were placed in a thermo-ventilated oven at $70{ }^{\circ} \mathrm{C}$ until the constant weight $\left(\mathrm{W}\right.$ cal.) reached $\left(R^{2}=0.9674\right)$. The irrigation, scheduled twice a day (at $7.00 \mathrm{am}$ and at $6.00 \mathrm{pm}$ ), was activated when the water content dropped below the pre-set threshold values of $10 \%$ WC, $20 \%$ WC, 30\% WC and 40\% WC (control) of the volume of the substrate. The same threshold values were adopted to determine irrigation interruption. The electrical conductivity of the water was $0.9 \mathrm{dS} \mathrm{m}^{-1}$. The experiment lasted 100 days. Figure 1 shows the trend of water volumetric content $(\%)$ in the different treatments during the trial.

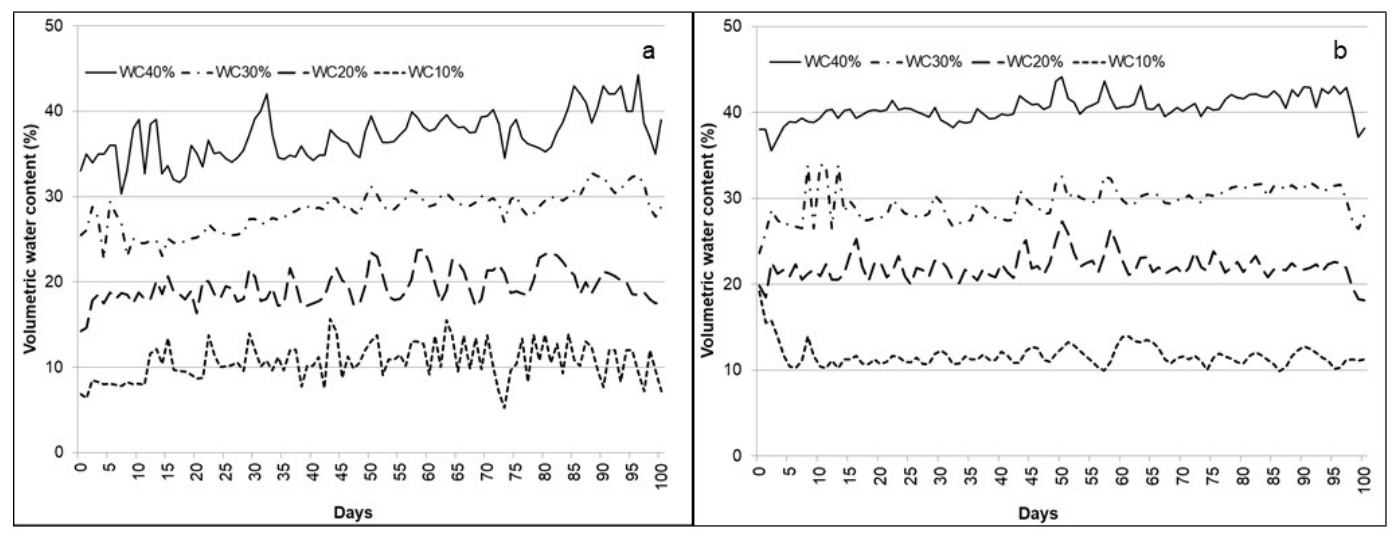

Figure 1. Volumetric water content (\%) in Polygala (a) and in Viburnum (b) during the trial.

\subsection{Meteorological Data}

The mean air temperature, relative humidity and global radiation during the experiment were measured by a data logger CR1000 (Campbell Scientific Ltd., Loughborough, UK). Average temperatures ranged between $20^{\circ} \mathrm{C}$ and $30{ }^{\circ} \mathrm{C}$, while the relative humidity (RH) was between $44 \%$ and $89 \%$ (Figure 2). The mean photosynthetic active radiation (PAR) ranged from $10 \mathrm{MJ} \mathrm{m}^{-2}$ and $15 \mathrm{MJ} \mathrm{m}^{-2}$ (data not shown).

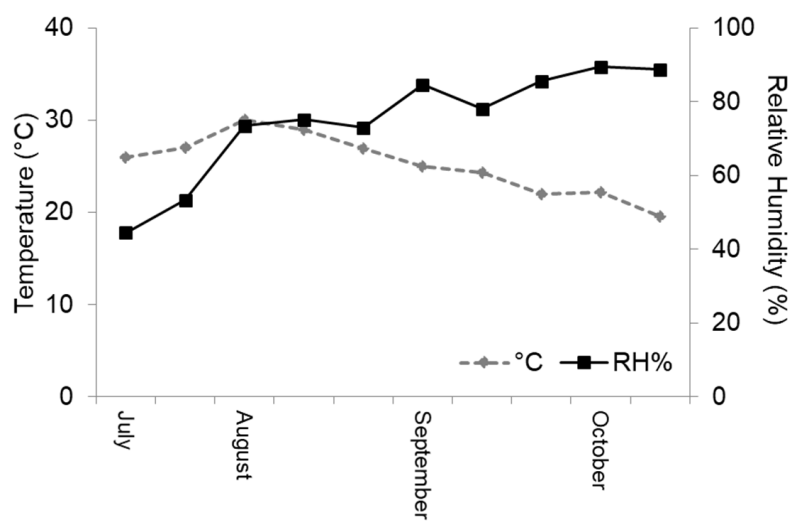

Figure 2. Mean temperature $\left({ }^{\circ} \mathrm{C}\right)$ and relative humidity $(\%)$ during the trial.

\subsection{Biomass, Leaf Area and SPAD Index}

At the end of the experiment, 12 plants per treatment (four per replicate) were separated into stems, leaves and roots. The dry matter (DM) of the different sections was obtained by putting weighed samples in a thermo-ventilated oven at $70{ }^{\circ} \mathrm{C}$ until they reached a constant weight. The specific leaf area (SLA) was determined in the same plants used to determine the dry biomass by the ratio between leaf area and leaf dry biomass. Total leaf number was measured and the unit leaf area was determined as the ratio of the total leaf area to total leaf number. The leaf area was determined with an area meter (Delta-T Devices Ltd, Cambridge, UK). SPAD index was measured on twenty fully expanded leaves by means of a portable chlorophyll meter SPAD-502 (Minolta Camera Co., Osaka, Japan). 


\subsection{Leaf Anatomy}

At the end of the experiment, in order to study the anatomy of leaves in relation to the water treatments, 12 mature ones were removed from the plants. Six longitudinal section per treatment were embedded in a cold-polymerizing historesin (Tecnovit 7100, Heraeus Kulzer GmbH \& CO. KG, Germany). With the use of a microtome (Leica Microsystems GmbH, Wetzlar, Gremany), samples were sliced into four to six $\mu \mathrm{m}$ thick sections and placed on slides for further microscopy analysis using an image analyzer (Leitz mod. ASM 68K, Hexagon Metrology GmbH, Wetzlar, Germany). The abaxial side of leaf sections was observed in order to study the stomata density using the silicon leaf impression method. Both, Polygala and Viburnum were hypostomatic. With the use of a $\times 400$ microscope both number and size of the stomata was determined on four different fields of vision of separate impressions of the lamina [13].

\subsection{Plant Physiological Measurements}

\subsubsection{Leaf Gas Exchanges and Chlorophyll a Fluorescence}

Midday gas exchange measurements were determined during the experimental period, every 25 days, between 10:00 and 14:00. On six leaves from each treatment, the assimilation rate $\left(\mathrm{A}_{\mathrm{N}}\right)$, the stomatal conductance $\left(\mathrm{g}_{\mathrm{s}}\right)$ and instantaneous water use efficiency (WUE) were determined with a portable IRGA (LCi, ADC Bioscientific Ltd., Hoddesdon, UK). After measuring photosynthesis, in the same leaves, the quantum yield of PSII was estimated with the modulated chlorophyll fluorimeter OS1-FL (Opti-Sciences Corporation, Tyngsboro, MA, USA). Each leaf was dark-adapted using cuvette clips (Opti-Sciences Corporation, Tyngsboro, MA, USA) for $20 \mathrm{~min}$.

The saturation of the photosystem was performed using a filtered $35 \mathrm{~W}$ halogen lamp (350 to $690 \mathrm{~nm}$ ). The $\mathrm{Fv} / \mathrm{Fm}$ ratio, used to express the chlorophyll a fluorescence, was calculated according to Schreiber et al. [34].

\subsubsection{Leaf Water Content}

Every 25 days, the predawn $(\psi \mathrm{pd})$ and midday $(\psi \mathrm{md})$ leaf water potential was determined in six plants per treatment. The method described by Scholander et al. [35] was adopted to estimate the leaf water potential, using a pressure chamber (PMS 600, PMS Instruments co., Corvellis, OR, USA).

\subsection{Statistical Analysis}

The experiment was conducted as a randomized complete block design with three replicates. The statistical analyses were carried out using CoStat version 6.311 (CoHortSoftware, Monterey, CA, USA), and two-way ANOVA was used. The differences between the means were determined using Tukey's test $(p<0.05)$. The interactions, when significant, are presented separately in the figures. Results of physiological measurements are shown as means \pm SE. Differences among treatments at each date were analyzed by one-way ANOVA at a significance level of $p<0.05$ according to Tukey's test. Principal component analysis (PCA) was performed over the correlation matrix among 20 selected variables using Minitab 16, LLC. The chosen variables were able to effectively indicate the stress situation. The plot of PC1 (43.6\%) vs. PC2 (33.5\%) is presented.

\section{Results}

\subsection{Biomass and Leaf Area}

Biomass accumulation was reduced in both ornamental shrubs due to the different irrigation treatments (Table 1, Figure 3). Total dry biomass in Polygala was reduced in $20 \%$ WC and 10\% WC (by $\sim 48 \%$ ), whereas in Viburnum, the reduction was only in 10\% WC by $~ 33 \%$ compared to the other treatments (Figure 3a). 
Table 1. Effects of species and water supply treatments on total, shoot and root dry biomass, root/shoot ratio (R/S), number of leaves, total and unit leaf area, specific leaf area (SLA) and SPAD index of potted Polygala and Viburnum plants. Four water supply treatments were considered: control irrigation (40\% WC); light deficit irrigation (30\% WC); medium deficit irrigation (20\% WC) and severe deficit irrigation $(10 \% \mathrm{WC})$.

\begin{tabular}{|c|c|c|c|c|c|c|c|c|c|c|}
\hline Species & Treatments & $\begin{array}{l}\text { Total Dry } \\
\text { Biomass } \\
\left.\text { (g plant }^{-1}\right)\end{array}$ & $\begin{array}{l}\text { Shoot Dry } \\
\text { Biomass } \\
\text { (g plant }^{-1} \text { ) }\end{array}$ & $\begin{array}{c}\text { Root Dry } \\
\text { Biomass } \\
\left.\text { (g plant }^{-1}\right)\end{array}$ & $\begin{array}{l}\text { R/S Ratio } \\
\left(\mathrm{g} \mathrm{g} \mathrm{g}^{-1}\right)\end{array}$ & $\begin{array}{c}\text { Leaf } \\
\text { (n. } \text { plant }^{-1} \text { ) }\end{array}$ & $\begin{array}{l}\text { Total Leaf Area } \\
\left(\mathrm{cm}^{2} \text { plant }^{-1}\right)\end{array}$ & $\begin{array}{c}\text { Unit Leaf } \\
\text { Area }\left(\mathrm{cm}^{2}\right. \\
\left.\text { plant }^{-1}\right)\end{array}$ & $\begin{array}{c}\text { SLA } \\
\left(\mathrm{cm}^{2} \mathrm{~g}^{-1}\right)\end{array}$ & $\begin{array}{l}\text { SPAD } \\
\text { Index }\end{array}$ \\
\hline Polygala & & $146.7 \pm 8.6^{b}$ & $110.8 \pm 9.6$ & $35.9 \pm 5.1^{b}$ & $0.31 \pm 0.0^{b}$ & $4443.6 \pm 507.9^{a}$ & $7304.6 \pm 779.9^{a}$ & $1.7 \pm 0.1^{\mathrm{b}}$ & $99.8 \pm 3.1^{\mathrm{a}}$ & $53.7 \pm 0.9^{b}$ \\
\hline \multirow[t]{5}{*}{ Viburnum } & & $167.2 \pm 9.5^{\mathrm{a}}$ & $109.4 \pm 6.8$ & $57.9 \pm 4.2^{\mathrm{a}}$ & $0.54 \pm 0.0^{\mathrm{a}}$ & $117.8 \pm 14.5^{\mathrm{b}}$ & $3408.7 \pm 393.9^{b}$ & $29.5 \pm 0.7^{\mathrm{a}}$ & $56.3 \pm 2.3^{b}$ & $73.8 \pm 1.5^{\mathrm{a}}$ \\
\hline & $40 \%$ WC & $192.2 \pm 5.8^{\mathrm{a}}$ & $136.4 \pm 2.7^{\mathrm{a}}$ & $55.8 \pm 6.2^{a}$ & $0.41 \pm 0.0$ & $3170.0 \pm 578.7^{a}$ & $7488.9 \pm 1131.1^{a}$ & $15.3 \pm 6.1$ & $88.1 \pm 5.7^{\mathrm{a}}$ & $60.4 \pm 2.4^{b}$ \\
\hline & $30 \% \mathrm{WC}$ & $193.9 \pm 4.9^{\mathrm{a}}$ & $135.3 \pm 5.3^{a}$ & $58.6 \pm 3.0^{\mathrm{a}}$ & $0.44 \pm 0.0$ & $2949.8 \pm 670.9^{a}$ & $6952.7 \pm 1214.2^{a}$ & $15.4 \pm 6.1$ & $82.0 \pm 4.5^{\mathrm{ab}}$ & $62.7 \pm 2.6^{b}$ \\
\hline & $20 \% \mathrm{WC}$ & $134.0 \pm 12.9^{b}$ & $92.4 \pm 3.4^{b}$ & $43.6 \pm 4.8^{\mathrm{ab}}$ & $0.46 \pm 0.1$ & $1713.9 \pm 533.4^{b}$ & $3971.9 \pm 680.2^{b}$ & $15.3 \pm 6.2$ & $74.8 \pm 4.2^{b}$ & $63.3 \pm 2.6^{b}$ \\
\hline & $10 \% \mathrm{WC}$ & $105.6 \pm 8.0^{c}$ & $76.2 \pm 2.3^{c}$ & $29.5 \pm 6.2^{b}$ & $0.32 \pm 0.1$ & $1289.0 \pm 560.6^{b}$ & $3013.3 \pm 527.4^{c}$ & $16.4 \pm 6.6$ & $67.0 \pm 3.7^{c}$ & $68.6 \pm 1.1^{a}$ \\
\hline
\end{tabular}

\begin{tabular}{|c|c|c|c|c|c|c|c|c|c|}
\hline \multicolumn{10}{|l|}{ Significance $^{1}$} \\
\hline Species (S) & ** & ns & $* * *$ & $* * *$ & $* * *$ & $* * *$ & $* * *$ & $* * *$ & **** \\
\hline Treatments ( $\mathrm{T})$ & $* * *$ & $* * *$ & $* * *$ & ns & $* * *$ & $* * *$ & ns & $* * *$ & $* *$ \\
\hline $\mathrm{S} \times \mathrm{T}$ & $* *$ & * & * & $* *$ & $* * *$ & $* * *$ & ns & ns & ns \\
\hline
\end{tabular}

${ }^{1}$ The statistical analysis was performed via two-way ANOVA; n.s. not significant; ${ }^{*}$ significant at $p<0.05 ;{ }^{* *}$ significant at $p<0.01$; ${ }^{* * *}$ significant at $p<0.001$. Values in the same column followed by the same letter are not significantly different at $p<0.05$ (Tukey's test). 
The reduction of shoot dry biomass in Polygala had a similar trend for the total dry biomass (by 44\%), while in Viburnum, the shoot dry biomass decreased in $20 \%$ WC and $10 \%$ WC (by 33\%) compared to the control and 30\% WC (Figure 3b). Root dry biomass was only modified in Polygala with a reduction of $63 \%$ in $20 \%$ WC and $10 \%$ WC compared to the control and $30 \%$ WC; Viburnum plants, considering this parameter, were not affected by the drought stress (Figure 3c).

The root-to-shoot ratio increased in Polygala plants grown under higher deficit irrigation conditions (10\% WC) (Figure 3d).

At the end of the trial, with the intensification of water stress ( $20 \% \mathrm{WC}$ and $10 \% \mathrm{WC}$ ), a reduction in the leaf number and area was observed. In particular, a reduction in leaf number by $50 \%$ and $54 \%$ in the 20\% WC treatment was observed in Polygala and Viburnum, respectively (Figure 3e). The reduction in total leaf area was similar to the reduction of leaf area with a decrease of about $50 \%$ in Polygala and by $53 \%$ in Viburnum (Figure $3 f$ ). The unit leaf area was significantly affected only by species (Table 1 ), while the SLA values was influenced by species and water treatments; in both species a significant reduction in $20 \%$ WC and $10 \%$ WC of $17 \%$ was observed (Table 1 ).

The SPAD index was influenced by species and water treatments; in particular the severe deficit irrigation $(10 \% \mathrm{WC})$ showing on average an increase of $10 \%$ on both species (Table 1$)$.

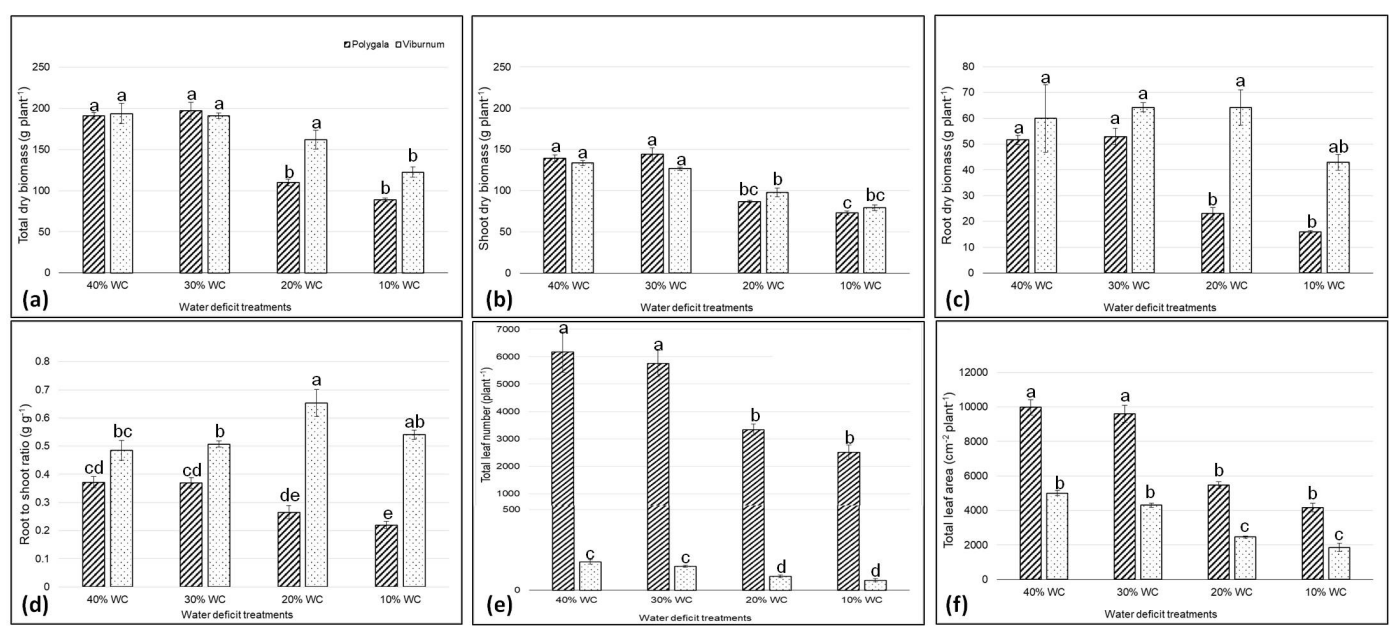

Figure 3. Interactions between species (Polygala and Viburnum) and water deficit treatments (40\% WC, 30\% WC, 20\% WC and 10\% WC) on total and shoot dry biomass (a,b), root dry biomass (c), root to shoot ratio (d), total leaf number (e) and total leaf area (f). Columns with the same letters are not significantly different, as determined by Tukey's test $(p<0.05)$.

\subsection{Leaf Anatomy}

In both species, water deficit treatments induced a modification of leaf total thickness (Table 2, Figure 4a). In Polygala, a reduction by $25 \%$ in $30 \%$ WC compared to plants irrigated at $40 \%$ WC, $20 \%$ WC and 10\% WC was observed. Plants of Viburnum subjected to drought stress treatment $(30 \% \mathrm{WC}$, $20 \%$ WC and $10 \%$ WC) showed an increase of $21 \%$, which significantly differed from the control plants (Figure 4a).

In Polygala, no significant modification was observed in palisade parenchyma, while, on the other hand, Viburnum showed an increase in $20 \%$ WC of $46 \%$ (Figure $4 \mathrm{~b}$ ).

In Polygala, no significant modifications were observed in spongy parenchyma; in Viburnum, $20 \%$ WC showed an increase by $27 \%$ (Figure 4 c).

Stomata density showed significant differences among the irrigation treatments only in Viburnum, with the highest density in the control $(40 \% \mathrm{WC})$ and the lowest in the more severe water stress treatments (Figure 4d). The water deficit treatments affected the stomata size only in Viburnum plants. The latter, in fact, showed a modification in the severe water treatments $(10 \% \mathrm{WC})$ with a significant reduction by $16 \%$ (Figure $4 \mathrm{e}$ ). 
Table 2. Effects of species and irrigation treatments on total number, palisade, spongy thickness $(\mu \mathrm{m})$, stomatal density $\left(\mathrm{n} / \mathrm{mm}^{2}\right)$ and size $(\mu \mathrm{m})$ of leaves of Polygala and Viburnum plants. Two-way ANOVA was used and the differences between the means were determined using Tukey's test $(p \leq 0.05)$.

\begin{tabular}{|c|c|c|c|c|c|c|}
\hline \multirow[t]{2}{*}{ Species } & \multirow[t]{2}{*}{ Treatments } & \multicolumn{3}{|c|}{$\begin{array}{c}\text { Thickness } \\
(\mu \mathrm{m})\end{array}$} & \multicolumn{2}{|c|}{ Stomata } \\
\hline & & Total & Palisade & Spongy & $\begin{array}{l}\text { Density } \\
\left(\mathrm{n} / \mathrm{mm}^{2}\right)\end{array}$ & $\begin{array}{l}\text { Size } \\
(\mu \mathrm{m})\end{array}$ \\
\hline Polygala & & $284.7 \pm 10.0^{b}$ & $69.9 \pm 2.5^{b}$ & $170.3 \pm 6.2^{b}$ & $175.8 \pm 2.5^{b}$ & $2.9 \pm 0.0^{b}$ \\
\hline \multirow[t]{5}{*}{ Viburnum } & & $432.4 \pm 14.8^{a}$ & $146.1 \pm 11.3^{\mathrm{a}}$ & $228.7 \pm 9.9^{\text {a }}$ & $204.0 \pm 5.6^{\mathrm{a}}$ & $2.6 \pm 0.1^{a}$ \\
\hline & $40 \% \mathrm{WC}$ & $331.6 \pm 15.6^{b}$ & $81.0 \pm 8.2^{c}$ & $203.2 \pm 15.7$ & $199.5 \pm 9.4^{\mathrm{ab}}$ & $2.8 \pm 0.1^{a}$ \\
\hline & $30 \% \mathrm{WC}$ & $331.5 \pm 41.7^{b}$ & $103.4 \pm 21.0^{b}$ & $184.2 \pm 20.1$ & $172.5 \pm 4.8^{c}$ & $2.9 \pm 0.1^{a}$ \\
\hline & $20 \% \mathrm{WC}$ & $384.5 \pm 45.7^{a}$ & $117.8 \pm 20.7^{a b}$ & $211.1 \pm 22.1$ & $185.3 \pm 3.0^{b c}$ & $2.9 \pm 0.0^{\mathrm{a}}$ \\
\hline & $10 \% \mathrm{WC}$ & $386.7 \pm 33.3^{a}$ & $129.8 \pm 23.6^{a}$ & $199.4 \pm 8.2$ & $202.3 \pm 7.0^{a}$ & $2.5 \pm 0.1^{b}$ \\
\hline \multicolumn{7}{|l|}{ Significance $^{\dagger}$} \\
\hline Species (S) & & $* * *$ & $* * *$ & ns & $* * *$ & $* * *$ \\
\hline Treatments (T) & & $* * *$ & $* * *$ & $* * *$ & $* * *$ & $* * *$ \\
\hline $\mathrm{S} \times \mathrm{T}^{+}$ & & $* * *$ & $* * *$ & $*$ & $* * *$ & $* * *$ \\
\hline
\end{tabular}

${ }^{\dagger}$ Values are means for the main effects of species (S) and irrigation treatment (T). ns-not significant; * significant at $p \leq 0.05 ;{ }^{* *}$ significant at $p \leq 0.01$; ** significant at $p \leq 0.001$. The values in the same column followed by the same letter are not significantly different at $p \leq 0.05$ (Tukey's test).
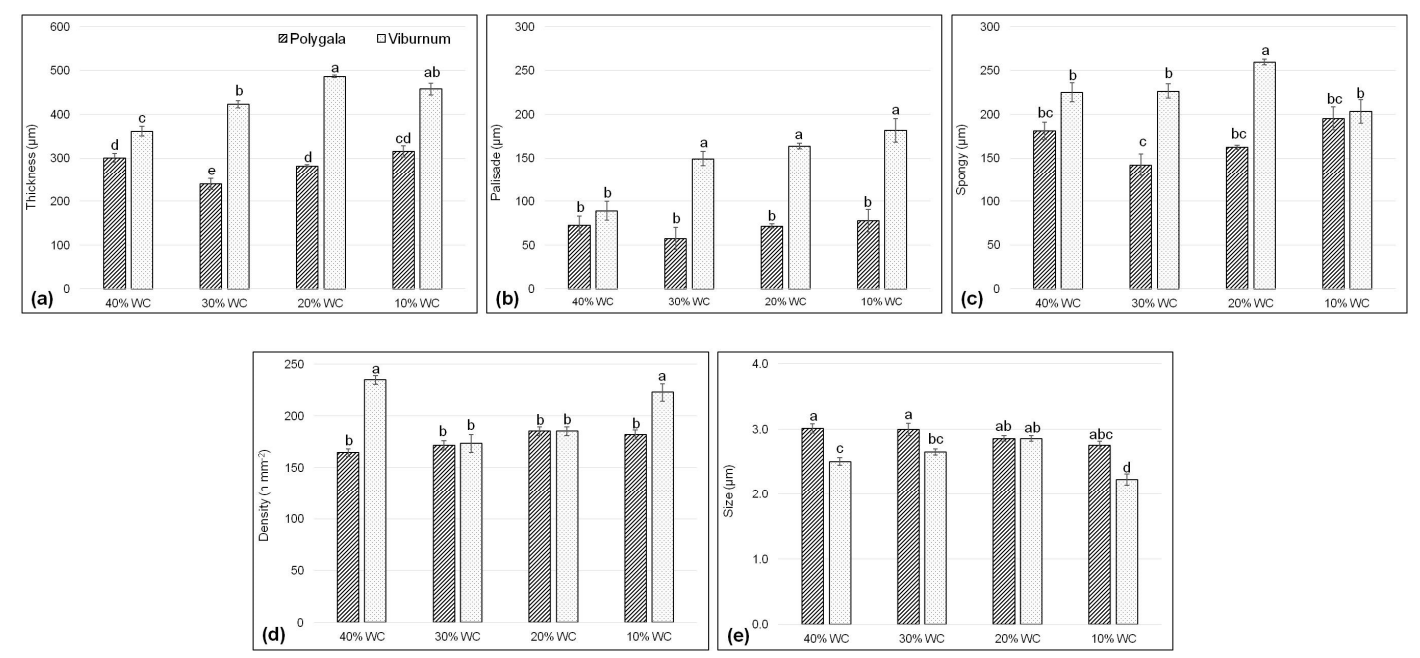

Figure 4. Interactions between species (Polygala and Viburnum) and water deficit treatments (40\% WC, $30 \% \mathrm{WC}, 20 \% \mathrm{WC}$ and 10\% WC) on thickness (a), palisade (b), spongy (c), stomata density (d) and size (e). Columns with the same letters are not significantly different, as determined by Tukey's test $(p<0.05)$.

\subsection{Plant Physiological Parameters}

Significant effects of water stress treatments in both species for net photosynthesis and leaf conductance were observed (Figure 5).

Since the first measurement, Polygala plants grown under severe water deficit (10\% WC) showed a reduction of $80 \%$ in $\mathrm{A}_{\mathrm{N}}$ compared to the control; a similar decrease was detected at the end of the trial in $20 \%$ WC plants. However, differences compared to the control occurred only after 50 days after the start of the experiment. The $30 \%$ WC plants did not show any significant differences as compared to control plants for the entire experimental time.

In Viburnum plants, after 25 days of water deficit, the decrease of net photosynthesis was significant for the more stressed thesis (20\% WC and $10 \% \mathrm{WC}$ ) and remained thereafter significant for the entire experimental period. Indeed, at the end of the trial, compared to the control, a reduction by $66 \%$ and $86 \%$ in $20 \%$ WC and $10 \%$ WC, respectively, was observed. In $30 \%$ WC Viburnum plants, a similar behavior was observed to that of control plants (Figure 5). 

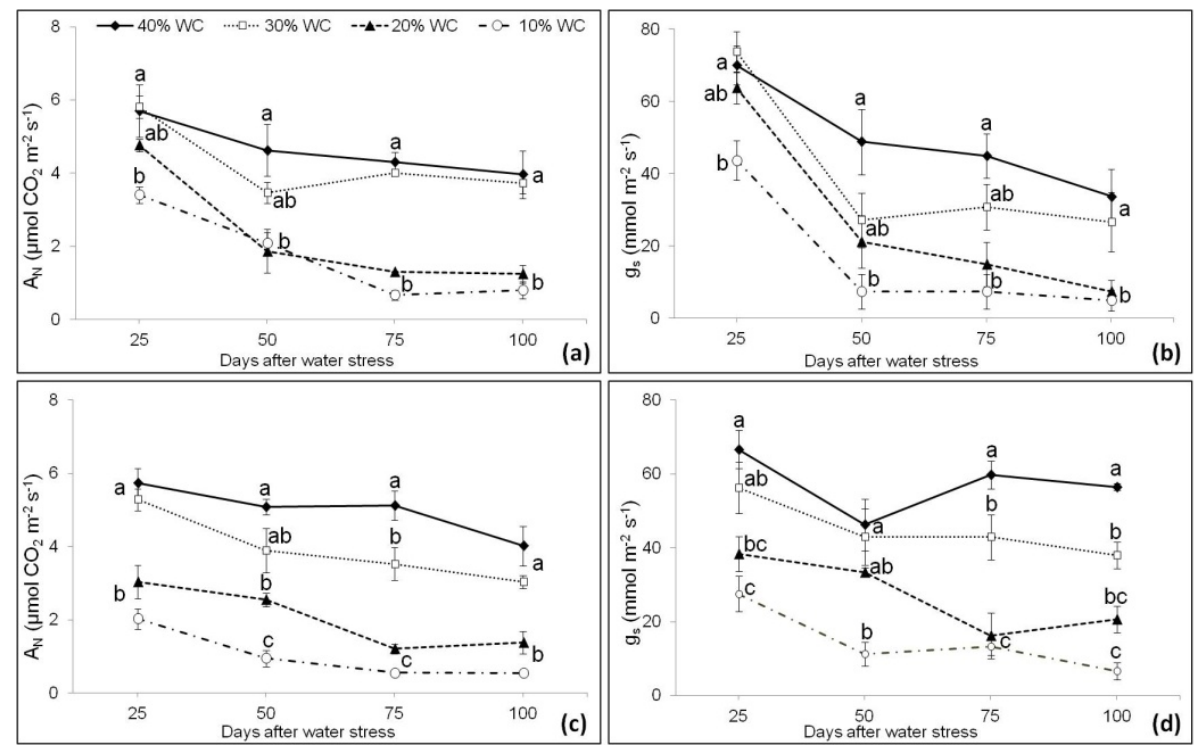

Figure 5. Net photosynthesis $\left(\mathrm{A}_{\mathrm{N}}\right)$ and leaf conductance $(\mathrm{gs})$ in Polygala $(\mathbf{a}, \mathbf{b})$ and Viburnum $(\mathbf{c}, \mathbf{d})$ during the experiment. Plants were irrigated to container capacity $(40 \% \mathrm{WC})$ or subjected to water stress treatments $(30 \% \mathrm{WC}, 20 \% \mathrm{WC}$ and $10 \% \mathrm{WC})$. Mean values \pm S.E. $(n=6)$. An absence of bars denotes a size smaller than the symbol. Different letters indicate significant differences between treatments at each sampling time as determined by Tukey's test $(p<0.05)$.

Similar results were detected for both species regarding leaf conductance (Figure 5).

In the two shrubs, a reduction in photosynthesis was linked to stomatal closure. A positive correlation was found between the photosynthetic rate and stomatal conductance of the two species during the experimental period with $R^{2}$ values of 0.8849 in Polygala and 0.9415 in Viburnum (Figure 6).

In Figure S1, trends of the transpiration rate and sub-stomatal $\mathrm{CO}_{2}$ are shown. Since the first measurement, Polygala plants grown under more stressed treatments (20\% WC and $10 \%$ WC) showed a reduction by $47 \%$ in E compared to the control and 30\% WC; a similar decrease was detected on the 75th day, while at the end of the trial, the treatments did not show significant differences (Figure S1a). In Viburnum plants, the decrease of E was significant for the more stressed thesis ( $20 \%$ WC and $10 \%$ WC) and remained thereafter significant for the entire experimental period. (Figure S1c). In Polygala, water use efficiency (WUE) did not show any significant differences among the control and the other treatments; only $20 \% \mathrm{WC}, 75$ days after starting the experiment, showed lower values (Figure S1b). Viburnum $10 \%$ WC showed an increase by $40 \%$ after 75 days.

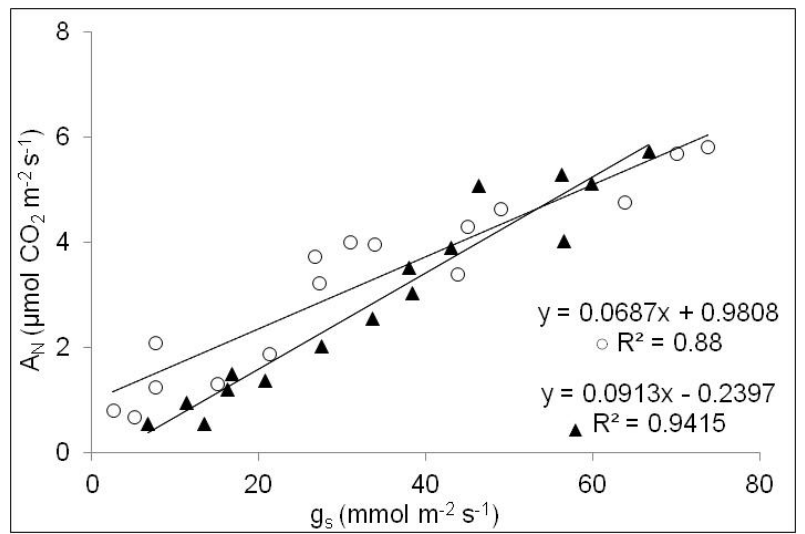

Figure 6. Correlation between net photosynthesis (A) and leaf conductance (gs) in Polygala ( $\mathbf{\Lambda}$ ) and Viburnum ( $\bigcirc$ ) during the experiment. 
In both species, water use efficiency (WUE) did not show any significant differences among the control and the other treatments; only $10 \%$ WC, 75 days after starting the experiment, showed lower values (Figure 7) both in Polygala and Viburnum.
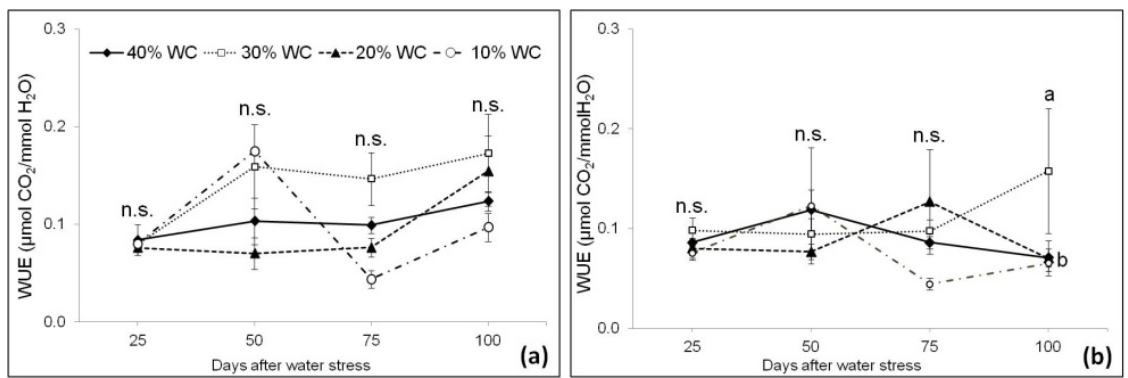

Figure 7. Water use efficiency (WUE) in Polygala (a) and Viburnum (b) during the experiment. Plants were irrigated to container capacity $(40 \% \mathrm{WC})$ or subjected to different levels of water stress treatments (30\% WC, $20 \%$ WC and 10\% WC). Mean values \pm S.E. $(n=6)$. An absence of bars denotes a size smaller than the symbol. Different letters indicate significant differences between treatments at each sampling time as determined by Tukey's test $(p<0.05)$.

The Fv/Fm ratio in Polygala showed significant differences in 20\% WC and 10\% WC treatments during the trial, with the lowest values at 75 and 100 days ( 0.75 and 0.73 , respectively). No significant differences for $\mathrm{Fv} / \mathrm{Fm}$ were observed between 30\% WC and the control (Figure 8a). In Viburnum, a reduction in the maximum quantum efficiency was observed only in severe deficit irrigated plants $(10 \%$ WC) starting from the 50th day until the end of the experiment with a value of 0.77 (Figure $8 \mathrm{~b}$ ).
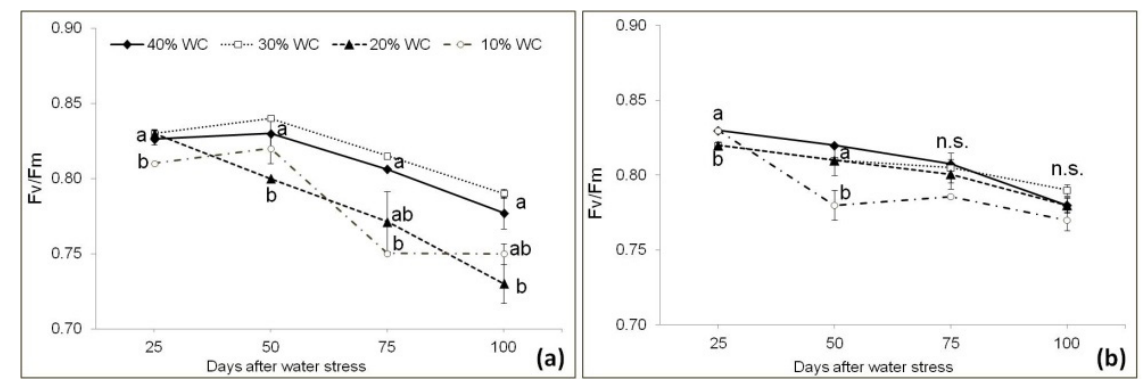

Figure 8. Maximum quantum efficiency of the PSII (Fv/Fm) in Polygala (a) and Viburnum (b) during trial. Plants were irrigated to container capacity $(40 \% \mathrm{WC})$ or subjected to water stress treatments $(30 \%$ WC, $20 \%$ WC and $10 \% \mathrm{WC})$. Mean values \pm S.E. $(n=6)$. An absence of bars denotes a size smaller than the symbol. Different letters indicate significant differences between treatments at each sampling time as determined by Tukey's test $(p<0.05)$.

Leaf water potential at pre-dawn ( $\Psi$ pd) in Polygala showed a significant reduction in 10\% WC for irrigated plants only. Compared to the mean value of the other three irrigation treatments, a decrease of $75 \%, 82 \%, 66 \%$ and $74 \%$ was detected after $25,50,75$ and 100 days. A similar trend was also observed in plants treated with a severe water deficit, such as for Viburnum (10\% WC) with a reduction of $70 \%$, $122 \%, 117 \%$ and $72 \%$ of leaf water potential over the average of the other treatments (Figure $9 a, b$ ).

In Polygala, the leaf water potential at midday ( $\Psi \mathrm{md}$ ) significantly decreased in all stress treatments compared to the control, reaching values of $-1.49,-1.62$ and $-2.04 \mathrm{MPa}$, respectively at the end of the experiment, in 30\% WC, 20\% WC and 10\% WC treated plants (Figure 9c). In Viburnum, a significant reduction was observed starting from the 75th from the experiment onset until the end of the trial, reaching values of $-0.82,-0.93,-1.22$ and $-1.48 \mathrm{MPa}$, respectively, in $30 \% \mathrm{WC}, 20 \% \mathrm{WC}$ and $10 \% \mathrm{WC}$ treatments (Figure 9d). 

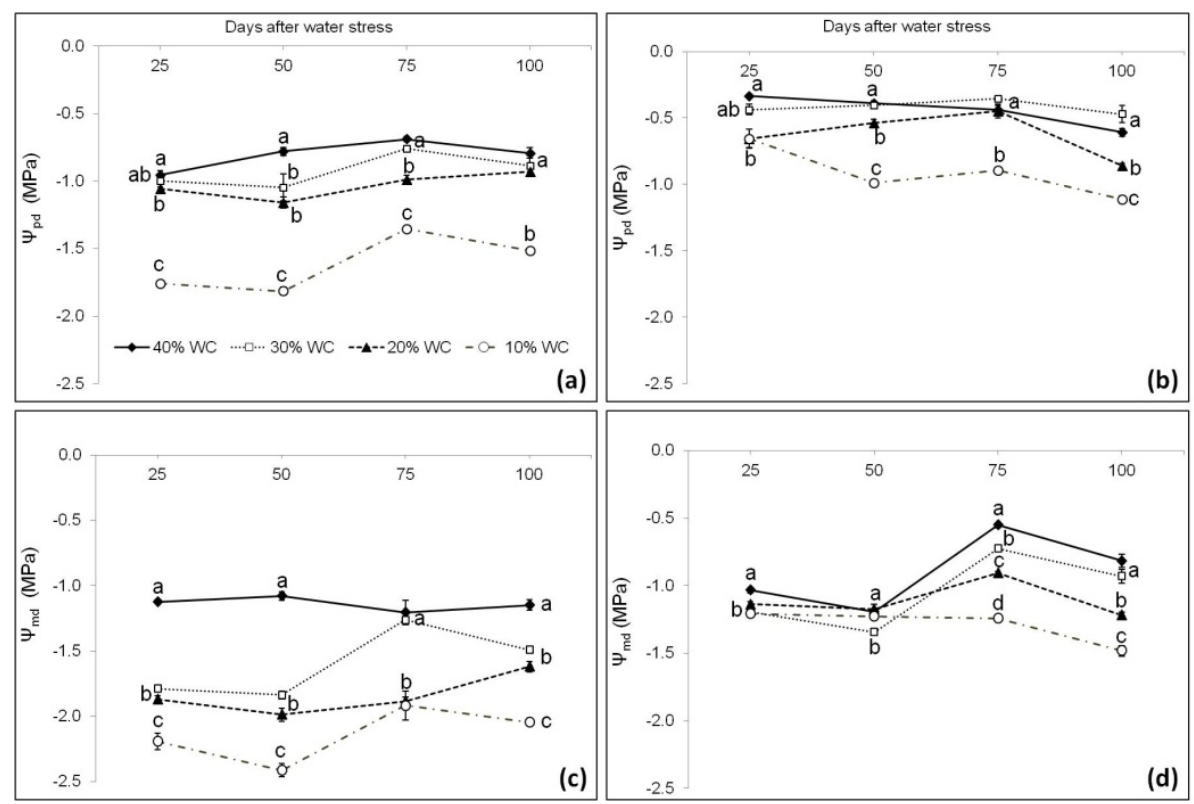

Figure 9. Leaf water potential ( $\Psi, \mathrm{MPa})$ at pre-dawn $(\mathbf{a}, \mathbf{b})$ and at midday $(\mathbf{c}, \mathbf{d})$ in Polygala (on the left) and in Viburnum (on the right) during the course of the trial. Plants were irrigated to container capacity (40\% WC) or subjected to water stress treatments (30\% WC, $20 \% \mathrm{WC}$ and $10 \% \mathrm{WC}$ ). The vertical bars represent the S.E. of means $(n=6)$. The absence of bars indicates that the size was less than the symbol. Different letters indicate significant differences between treatments at each sampling time as determined by Tukey's test $(p<0.05)$.

\subsection{Principal Component Analysis (PCA)}

Processed data on the principal component analysis (PCA) resulted, for both species, in a cumulative variance of 43 and $77 \%$ for PC1 and PC2 respectively, associated to Eigen values of 8.7 and 6.7. From the present analysis appeared quite clear how the two species, subjected to different drought stress treatments, clearly resulted separated in the distribution plot (Figure 10) showing proportional values of 43.6 and 33.5 for PC1 and PC2 respectively.

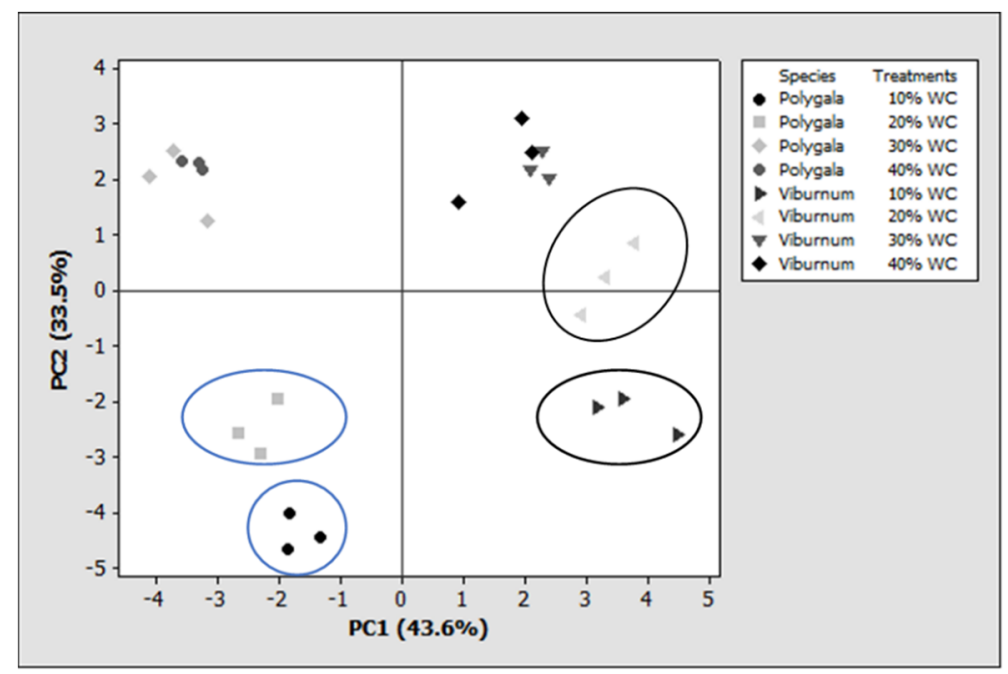

Figure 10. Principal component analysis (PCA) was performed over the correlation matrix among 20 selected variables. The plot of PC1 (43.6\%) vs. PC2 (33.5\%) is presented.

Furthermore, also water shortage treatments at 10\% WC and 20\% WC resulted clearly separated, indicating a specific and stress-intensity response in both species, whereas 30\% WC and 40\% WC didn't 
show any clear spatial distribution, indicating that the stress intensity did not affect any physiological and morphological plant response.

In the PCA, PC1 vs. PC2 a negative correlation was detected in SLA, leaf number, stomata size, total leaf area, shoot dry biomass, A, gs, WUE and total dry biomass, while a positive correlation was detected in $\Psi \mathrm{pd}, \mathrm{Fv} / \mathrm{Fm}, \Psi \mathrm{md}$, root dry biomass, R/S ratio, unit leaf area, spongy palisade thickness stomata density and SPAD (Figure 11), describing the tendency of the plants to allocate the synthesized organic matter in the roots instead of the shoots in order to cope with water stress conditions. The main changes in the above ground part of the plants were detected on a general reduction of leaves number and, as a consequence, on the total leaf area. At the same time, the plants modify the unit leaf area (Figure 12).

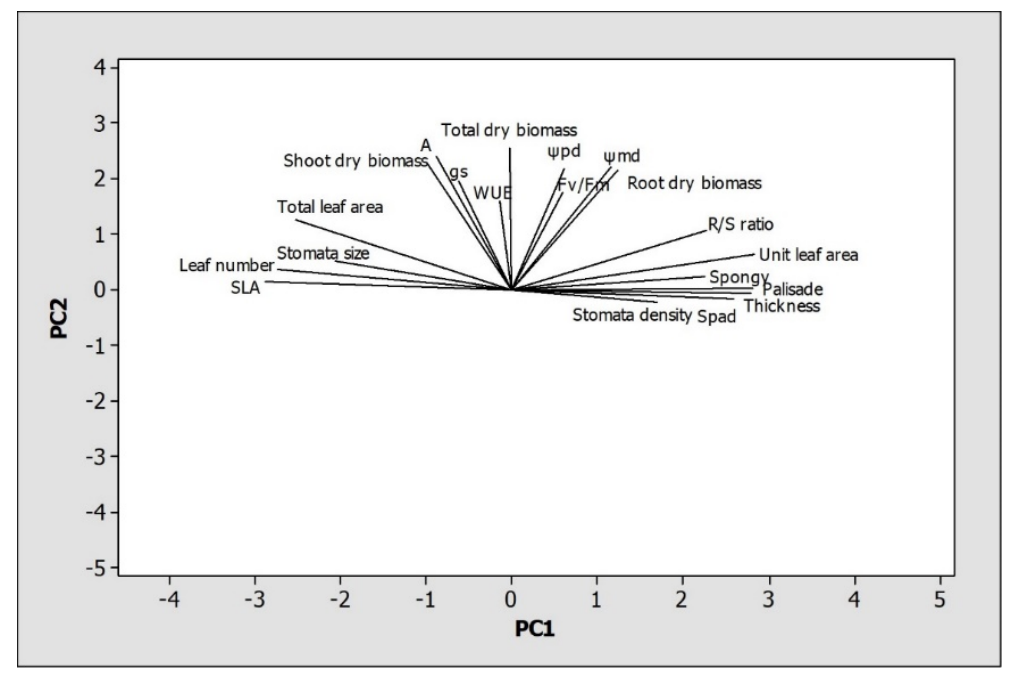

Figure 11. Principal component analysis (PC1 vs PC2) of Polygala and Viburnum species subjected to drought stress treatments: loading plot and distribution of samples in the consensus space.

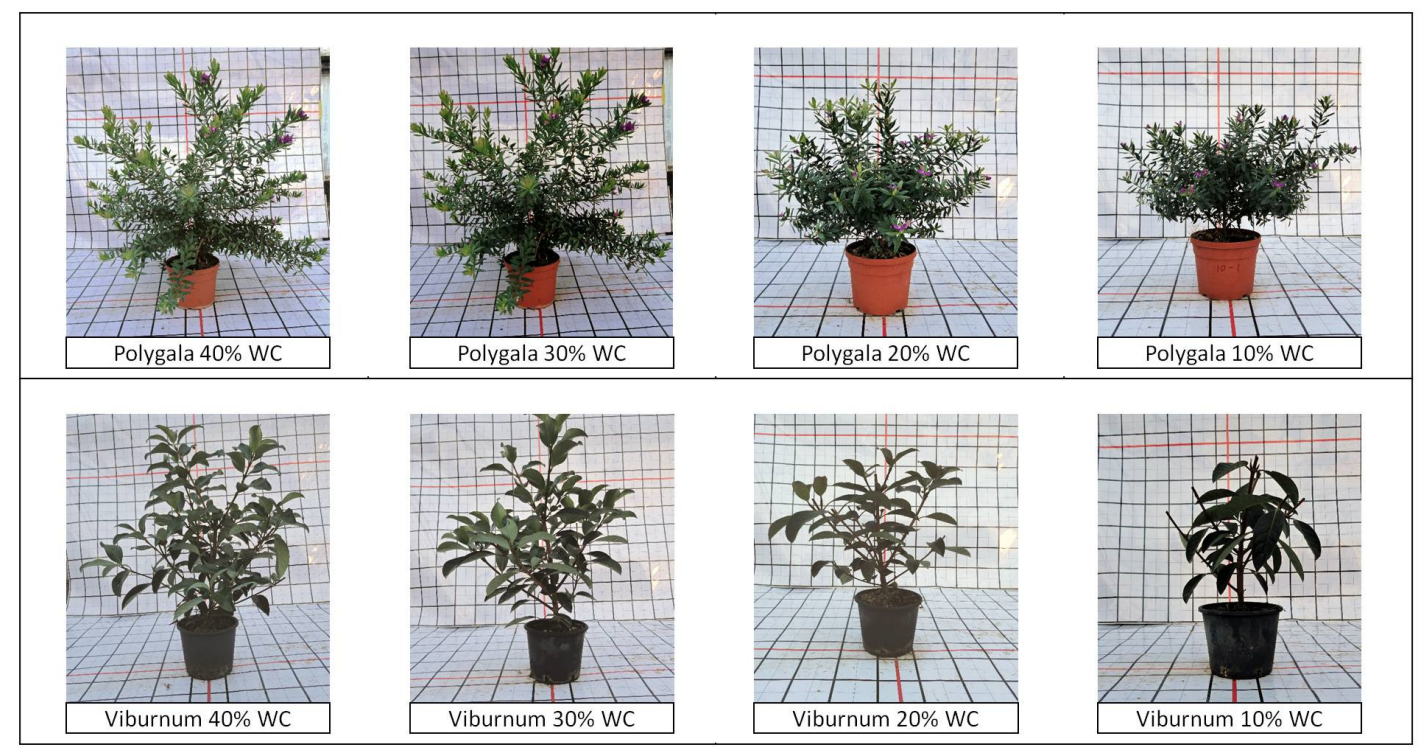

Figure 12. Polygala and Viburnum plants irrigated to container capacity ( $40 \% \mathrm{WC}$ ) or subjected to water stress treatments ( $30 \% \mathrm{WC}, 20 \% \mathrm{WC}$ and $10 \% \mathrm{WC}$ ) at the end of the trial.

\section{Discussion}

The selection of highly tolerant drought stress species plays an important role in planning private and public ornamental green areas in urban and peri-urban environments. In many urban areas, the irrigation of green areas represents a high amount of urban water consumption (between $40 \%$ 
and $70 \%$ ) [36]. However, in environments with limited water availability, the selection of ornamental plants with a high WUE is almost compulsory. The sustainability of green areas greatly depends on the performance of ornamental plants under a deficient water supply. Nevertheless, the plant chosen should have a drought tolerance threshold compatible with the water fraction available without showing any ornamental quality losses such as leaf yellowing or abscission.

Regarding the suitable selection of drought-tolerant plants, it is important to understand the physiological and/or biochemical responses of plant species to water stress [13,37]. Our results showed that there are differences in the drought responses of two shrubs, despite both of them being able to overcome this environmental limitation. The drought stress, in fact, had different effects on the biomass repartition according to the species.

Viburnum and Polygala, in fact, showed different morphological adaptations to overcome the imposed drought stress, reducing leaf number and area, and dry biomass. These adaptations are similar to those found in roses [38], Callistemon [8,39], Spirea nipponica 'Snowmound', Pittosporum eugenioides 'Variegatum', Viburnum nadum [40], and some Mediterranean shrubs [41].

The growth reduction of plants, and hence the lower plant biomass, represents the final expression of a number of processes analyzed to determine salt and water stress tolerance [28,32,42]. In our study, in both species, the severe drought stress (20\% WC and $10 \% \mathrm{WC})$ led in particular to a decrease of the shoot dry biomass. The tolerance level to drought stress should be considered an important factor to save water. Even if shrubs reduced biomass, they managed to maintain their ornamental value. Deficit irrigation reduces plant growth in several ornamental species [12,43-47], although the reaction to drought stress widely varies among species, being a typical species-specific response. The lower shoot growth is also common in salt stress, caused by reduction of new leaf emission and leaf growth [48]. The leaf area reduction allow the plants to reduce water loss by transpiration. This is a typical stress-avoidance mechanism adopted by plants to overcome water stress condition, as reported for different shrub species in drought environments $[12,13,39,41]$. In the face of a marked reduction of shoot biomass, the root biomass is increased to allow the better exploration of the soil to find available water. In fact, the plants increase the root to shoot ratio to overcome the drought stress, which reduces water consumption and increases water absorption [49,50]. This response was observed in Viburnum plants $(20 \% \mathrm{WC}$ and $10 \% \mathrm{WC})$, where there has been a redistribution of the dry biomass to benefit the roots at the expense of shoots (higher root/shoot ratio). The increase in R/S ratio observed in our study was the result of a greater reduction in shoot biomass rather than an increase in root biomass. A higher root/shoot ratio could allow us to obtain "hardy" plants which are able to rapidly overcome the transplant crisis [51] and better adapt to subsequent water shortages [52]. A lower deficit irrigation $(30 \% \mathrm{WC})$ in the nursery phase is able to reduce the excessive shoot growth without compromising the ornamental value and avoiding chemical growth retardants [53]. Unlike, in fact, what occurs for salt stress or from marine aerosol, browning on the leaf blade rarely takes place.

A drastic water shortage reduced the number of leaves and total leaf area in both studied species. Different papers have also reported the decrement of these parameters in relation to low soil water availability [54-59]. Polygala drought-stressed plants showed a more evident reduction in leaf number; this is correlated with the high number of leaves that characterized this species. One of the main plant responses to drought is the reduction of leaf area, because reducing the surface area limits water loss via transpiration [60]. The leaf area represents the leaf adaptation to environmental changes, and it is connected to plant growth, light interception, gas exchange [61], and also ornamental plant value. The plant capacity to reduce leaf area is typically a drought-tolerant response [61]. This strategy is similar to plant response to salt stress; in this condition, however, the degree of tolerance is strictly related to the aesthetic value, which can be compromised by browning on the leaf blade [62].

High water deficit can also modify the concentrations of chlorophyll and carotenoid [63]. A reduced chlorophyll content was found in Catharanthus roseus [64], Helianthus annuus [65] and Vaccinium myrtillus [66] grown in severe water stress conditions; an increase of this parameter was observed in moderate and severe water stress conditions, similar to that shown in our results [67]. In our study, 
an increase of SPAD index was found in severe drought stress (10\% WC). Furthermore, the increase in chlorophyll content due to moderate and intense water stress could be the effect of the growth decline in cells related to chlorophyll synthesis [68]. At any rate, the influence of chlorophyll content on the photosynthetic rate in Thypa latifolia is slight [69]. The chlorophylls and carotenoids are important pigments which contribute to the visual appearance and ornamental quality of the plants. Therefore, ornamental drought-tolerant plants should not show significant variations under the water regimes available.

During drought stress conditions, changes occur in the leaf anatomy. Some studies indicated that slight variations in the leaf thickness determined significant modifications in gas exchange in some plant species, while others demonstrated large plasticity in terms of leaf thickness with little variation in photosynthetic capacity [70]. Studies on leaf anatomical characteristics of Passiflora species showed that $P$. setacea was the one, among the five species of the same genera investigated, with the highest survivability under water limitation due to its capacity to tolerate severe drought stress [71]. In our study, Viburnum plants subjected to drought conditions showed an increase in palisade parenchyma thickness; this is in accordance to Guerfel et al. [72], who observed in two Tunisian olive cultivars subjected to water stress an increase in palisade parenchyma thickness during water stress in drought-tolerant plants.

The palisade parenchyma is directly linked to photosynthesis, because the higher development of this tissue could enable a greater fixation of $\mathrm{CO}_{2}$ with faster stomata opening [73]. Under low water availability, plants modify the size and density of their stomata as an adaptation strategy to water stress. In our study, both shrubs significantly reduce the size of their stomata. Only Viburnum, however, reduced its stomata density. The reduction of the stomata number and size on the leaf surface has an evident influence on water loss.

Smaller stomata allow a better control of drought stress and regulation of water use efficiency [20]. The modification of the size and the density of stomata represents a typical avoidance strategy during drought stress conditions.

With the reduction of transpiration, the water use efficiency generally increases [74]. Water use efficiency (WUE, A/E) is adopted to indicate the water amount used by plants for growing. Some papers reported that stressed plants are more able to utilize the energy obtained by photosynthesis, thanks to higher $\mathrm{A} / \mathrm{E}[15,75]$. In our study, drought stress did not affect this process, indicating that the two shrubs could efficiently use water resources under moderate and severe water stress conditions.

The leaf water potential was highly different between the control and severe water stress conditions in both species. In different species, subjected to drought stress conditions stomata closure is a consequence to water potential adjustment [20]. The water potential measured predawn appeared to be a very effective parameter for highlighting the different degree of drought stress to which Polygala and Viburnum plants, in relation to the different water stress treatment, encountered during the trial. For both species, in fact, the values of the water potential were very low at $10 \% \mathrm{WC}$, although the differences, compared to the control, were clearly lower for Viburnum than for Polygala, confirming that the latter has a poor tolerance to water deficit. The reduction of leaf water potential is a frequent response to water stress, also in drought-tolerant plants [76]. The capacity to maintain a high leaf water potential at $40 \%$ WC showed that the plants did not experience water limitation.

Net photosynthesis showed different values in relation to water stress conditions during the experimental period. This parameter, in both species, decreased with the lowering of the water content. The differences among the treatments were particularly evident at the end of the trial, especially in Polygala plants.

The closure of stomata was a major factor affecting the reduction of $g_{s}$ and $A_{N}$ under drought stress conditions in both species. The variations in the photosynthetic activity are largely attributable to changes in stomatal conductance, as can be seen from the high degree of positive correlation between these two parameters. The result confirms what was found by other authors in different shrub species [77]. The decrease in $\mathrm{g}_{\mathrm{s}}$ represents a mechanism to overcome drought stress and limit water 
loss. This is according to Hessini et al. [78], where in plants of Spartina alterniflora subjected to drought at the end of the trial, the stressed plants showed significantly lower stomatal conductance.

Drought stress influences the sensitivity of the photosynthetic apparatus to photoinhibition [79-81]. Beyond affecting stomatal closure, drought stress reduced gas exchange in the plants by reducing transpiration and photosynthetic rates [41].

Under drought stress, photoinhibition can increase because the plant's capacity to use the available light can be reduced $[80,82]$. Our results showed that water stress did not influence photoinhibition, because the values of $\mathrm{Fv} / \mathrm{Fm}$ were within the typical ranges of healthy plants [0.80;22]. This demonstrates that the damage of the foliar tissues is not irreversible, that PSII was not permanently damaged [32], and that the chloroplasts of Mediterranean species are able to adopt different mechanisms during drought stress conditions to avoid photo-inhibitory processes, such as the mechanism to dissipate the reducing power produced by the PSII.

This parameter also did not show wide variation in the previous experiment conducted by Farieri et al. [32], indicating that the plants, even in conditions of saline aerosol, were able to preserve leaf functionality.

The PCA analysis demonstrated that the treatments with higher water ability did not differ between both species, in turn indicating that the level of stress did not affect the plant morphology and physiology. Moreover, the data demonstrated that the two species have different drought responses, since there was no overlap among species and treatments.

The plants try to implement a series of modifications to compensate the reduction of leaf area, leading to a series of structural modifications of the leaf.

\section{Conclusions}

The results of this study indicate that the ornamental shrubs developed avoidance mechanisms in response to drought stress. As for saline aerosol, even for drought stress, net assimilation is the most complete parameter of leaf functionality associated with chlorophyll a fluorescence. The ornamental shrubs have modified gas exchange, leaf number and area, and root-to-shoot ratio. These morpho-physiological adjustments could to some extent mitigate the effect of drought stress under field conditions.

Overall, our shrubs were tolerant to drought treatment, particularly the Viburnum plants. These findings supported the use of this species in Mediterranean areas, where the spring and the summer are very warm and dry and hence are characterized by drought stress. The species' adaptability to water stress was similar to that observed with salt aerosol stress, as well as the degree of adaptation. The similar plant strategies to overcome these two frequent stresses in the Mediterranean coastal areas, linked to the same strategies used by plants, allow us to assume that the possibility of identifying plants that can simultaneously counter environmental stresses is concrete. The environmental sustainability of the green areas in urban and peri-urban sites is extremely important in locations with lower water availability. The innovative and original results arising from our work are represented by the strategies for the identification of water regimes that can be compatible with low water availability and the retaining of ornamental quality. In particular, the water deficit of $30 \%$ for the two species and $20 \%$ for Viburnum can be satisfactorily used from a broad sustainability point of view.

Supplementary Materials: The following is available online at http://www.mdpi.com/2073-4395/9/7/381/s1, Figure S1: Transpiration rate (E) and Sub-stomatal CO2 (Ci) in Polygala (a,b) and Viburnum (c,d) during the experiment.

Author Contributions: Conceptualization, A.T., S.T. and D.R.; Methodology and Software S.T.; Collected the Data V.D.L. Writing-Original Draft Preparation, A.T. and S.T.; Writing-Review and Editing, D.R. All authors have read and approved the manuscript.

Funding: This research work was supported by the project "Sostenibilità del processo produttivo in filiere rappresentative dell'agricoltura mediterranea: innovazioni biologiche, tecniche ed agronomiche" funded by the Università degli Studi di Catania.

Conflicts of Interest: The authors declare no conflict of interest. 


\section{References}

1. WWAP (World Water Assessment Programme). The United Nations World Water Development Report 2014: Water and Energy; UNESCO: Paris, France, 2014.

2. Paz, S.; Negev, M.; Clermont, A.; Green, M.S. Health aspects of climate change in cities with Mediterranean climate, and local adaptation plans. Int. J. Environ. Res. Public Health 2016, 13, 438. [CrossRef] [PubMed]

3. Dallman, P.R. Plant Life in the World's Mediterranean Climates: California, Chile, South Africa, Australia, and the Mediterranean Basin; University of California Press: Oakland, CA, USA, 1998.

4. Rundel, P.W.; Arroyo, M.T.; Cowling, R.M.; Keeley, J.E.; Lamont, B.B.; Vargas, P. Mediterranean biomes: Evolution of their vegetation, floras, and climate. Annu. Rev. Ecol. Evol. Syst. 2016, 47, 383-407. [CrossRef]

5. Munné-Bosch, S.; Peñuelas, J. Drought-induced oxidative stress in strawberry tree (Arbutus unedo L.) growing in Mediterranean field conditions. Plant Sci. 2004, 166, 1105-1110. [CrossRef]

6. Filella, I.; Llusia, J.; Piñol, J.; Peñuelas, J. Leaf gas exchange and fluorescence of Phillyrea latifolia, Pistacia lentiscus and Quercus ilex saplings in severe drought and high temperature conditions. Environ. Exp. Bot. 1998, 39, 213-220. [CrossRef]

7. Ferrante, A.; Trivellini, A.; Scuderi, D.; Romano, D.; Vernieri, P. Post-production physiology and handling of ornamental potted plants. Postharvest Biol. Technol. 2015, 100, 99-108. [CrossRef]

8. Álvarez, S.; Sánchez-Blanco, M.J. Changes in growth rate, root morphology and water use efficiency of potted Callistemon citrinus plants in response to different levels of water deficit. Sci. Hortic. 2013, 156, 54-62. [CrossRef]

9. Medrano, H.; Flexas, J.; Galmés, J. Variability in water use efficiency at the leaf level among Mediterranean plants with different growth forms. Plant Soil 2009, 317, 17-29. [CrossRef]

10. Álvarez, S.; Rodríguez, P.; Broetto, F.; Sánchez-Blanco, M.J. Long term responses and adaptive strategies of Pistacia lentiscus under moderate and severe deficit irrigation and salinity: Osmotic and elastic adjustment, growth, ion uptake and photosynthetic activity. Agric. Water Manag. 2018, 202, 253-262. [CrossRef]

11. Toscano, S.; Ferrante, A.; Romano, D. Response of Mediterranean ornamental plants to drought stress. Horticulturae 2019, 5, 6. [CrossRef]

12. Cirillo, C.; Rouphael, Y.; Caputo, R.; Raimondi, G.; De Pascale, S. The influence of deficit irrigation on growth, ornamental quality, and water use efficiency of three potted Bougainvillea genotypes grown in two shapes. Hort. Sci 2014, 49, 1284-1291. [CrossRef]

13. Toscano, S.; Ferrante, A.; Tribulato, A.; Romano, D. Leaf physiological and anatomical responses of Lantana and Ligustrum species under different water availability. Plant Physiol. Biochem. 2018, 127, 380-392. [CrossRef] [PubMed]

14. Fraser, L.H.; Greenall, A.; Carlyle, C.; Turkington, R.; Ross Friedman, C. Adaptive phenotypic plasticity of Pseudoroegneria spicata: Response of stomatal density, leaf area and biomass to changes in water supply and increased temperature. Ann. Bot. 2009, 103, 769-775. [CrossRef] [PubMed]

15. Liu, F.; Stützel, H. Biomass partitioning, specific leaf area, and water use efficiency of vegetable amaranth (Amaranthus spp.) in response to drought stress. Sci. Hortic. 2004, 102, 15-27. [CrossRef]

16. Farooq, M.; Wahid, A.; Kobayashi, N.; Fujita, D.; Basra, S.M.A. Plant drought stress: Effects, mechanisms and management. In Sustainable Agriculture; Springer: Dordrecht, The Netherlands, 2009; pp. 153-188.

17. Vallejo, V.R.; Bautista, S.; Cortina, J. Restoration for soil protection after disturbances. In Life and Environment in the Mediterranean; Trabaud, L., Ed.; Wit Press: Southampton, UK, 2000; pp. 301-343.

18. Vilagrosa, A.; Hernández, E.I.; Luis, V.C.; Cochard, H.; Pausas, J.G. Physiological differences explain the co-existence of different regeneration strategies in Mediterranean ecosystems. New Phytol. 2014, 201, 1277-1288. [CrossRef] [PubMed]

19. Anjum, S.; Xie, X.Y.; Wang, L.C.; Saleem, M.F.; Man, C.; Wang, L. Morphological, physiological and biochemical responses of plants to drought stress. Afr. J. Agric. Res. 2011, 6, 2026-2032. [CrossRef]

20. Cirillo, C.; De Micco, V.; Rouphael, Y.; Balzano, A.; Caputo, R.; De Pascale, S. Morpho-anatomical and physiological traits of two Bougainvillea genotypes trained to two shapes under deficit irrigation. Trees 2017, 31, 173-187. [CrossRef]

21. Campbell, D.R.; Wu, C.A.; Travers, S.E. Photosynthetic and growth responses of reciprocal hybrids to variation in water and nitrogen availability. Am. J. Bot. 2010, 97, 925-933. [CrossRef] 
22. Maxwell, K.; Johnson, G.N. Chlorophyll fluorescence-A practical guide. J. Exp. Bot. 2000, 51, 659-668. [CrossRef]

23. Demmig, B.; Björkman, O. Comparison of the effect of excessive light on chlorophyll fluorescence (77K) and photon yield of $\mathrm{O}_{2}$ evolution in leaves of higher plants. Planta 1987, 171, 171-184. [CrossRef]

24. Huxley, A.J.; Griffiths, M. New Royal Horticultural Society Dictionary of Gardening; Grove's Dictionaries Inc.: New York, NY, USA, 1999.

25. Meerow, A.W.; Ayala-Silva, T. Polygala myrtifolia 'Chapman Field', an everblooming subtropical flowering shrub. HortScience 2005, 40, 864-865. [CrossRef]

26. Fini, A.; Ferrini, F.; Frangi, P.; Amoroso, G.; Giordano, C. Growth, leaf gas exchange and leaf anatomy of three ornamental shrubs grown under different light intensities. Eur. J. Hortic. Sci. 2010, 75, 111-117.

27. Bussotti, F.; Ferrini, F.; Pollastrini, M.; Fini, A. The challenge of Mediterranean sclerophyllous vegetation under climate change: From acclimation to adaptation. Environ. Exper. Bot. 2014, 103, 80-98. [CrossRef]

28. Cirillo, C.; Rouphael, Y.; Caputo, R.; Raimondi, G.; Sifola, M.I.; De Pascale, S. Effects of high salinity and the exogenous application of an osmolyte on growth, photosynthesis, and mineral composition in two ornamental shrubs. J. Hortic. Sci. Biotechnol. 2016, 91, 14-22. [CrossRef]

29. Garcia-Navarro, M.C.; Evans, R.Y.; Montserrat, R.S. Estimation of relative water use among ornamental landscape species. Sci. Hortic. 2004, 99, 163-174. [CrossRef]

30. Gómez-Bellot, M.J.; Ortuño, M.F.; Nortes, P.A.; Bernavé, A.; Fernández, F.; Sánchez-Blanco, M.J. Effectiveness of bacterial inoculation in alleviation of salinity on water status, mineral content, gas exchange and photosynthetic parameters of Viburnum tinus L. plants. Sci. Hortic. 2018, 237, 303-310. [CrossRef]

31. Cirillo, C.; De Micco, V.; Arena, C.; Carillo, P.; Pannico, A.; De Pascale, S.; Rouphael, Y. Biochemical, Physiological and anatomical mechanisms of adaptation of Callistemon citrinus and Viburnum lucidum to $\mathrm{NaCl}$ and $\mathrm{CaCl} 2$ salinization. Front Plant Sci. 2019, 10, 742. [CrossRef] [PubMed]

32. Farieri, E.; Toscano, S.; Ferrante, A.; Romano, D. Identification of ornamental shrubs tolerant to saline aerosol for coastal urban and peri-urban greening. Urban For. Urban. Green. 2016, 18, 9-18. [CrossRef]

33. Starr, J.L.; Paltineanu, I.C. Methods for Measurement of Soil Water Content: Capacitance Devices; Methods of Soil Analysis; United States Department of Agriculture, Agricultural Research Service: Washington, DC, USA, 2002.

34. Schreiber, U.; Schliwa, U.; Bilger, W. Continuous recording of photochemical and non-photochemical chlorophyll fluorescence quenching with a new type of modulation fluorometer. Photosynth. Res. 1986, 10, 51-62. [CrossRef] [PubMed]

35. Scholander, P.F.; Bradstreet, E.D.; Hemmingsen, E.A.; Hammel, H.T. Sap pressure in vascular plants: Negative hydrostatic pressure can be measured in plants. Science 1965, 148, 339-346. [CrossRef]

36. Lockett, L.; Montague, T.; McKenney, C.; Auld, D. Assessing public opinion on water conservation and water conserving landscapes in the semiarid southwestern United States. HortTechnology 2002, 12, 392-396. [CrossRef]

37. Cicevan, R.; Al Hassan, M.; Sestras, A.F.; Prohens, J.; Vicente, O.; Sestras, R.E.; Boscaiu, M. Screening for drought tolerance in cultivars of the ornamental genus Tagetes (Asteraceae). Peer] 2016, 4, e2133. [CrossRef]

38. Niu, G.; Rodriguez, D.S.; Aguiniga, L.; Mackay, W. Salinity tolerance of Lupinus havardii and Lupinus texenis. HortScience 2007, 42, 526-528. [CrossRef]

39. Álvarez, S.; Navarro, A.; Nicolás, E.; Sánchez-Blanco, M.J. Transpiration, photosynthetic responses, tissue water relations and dry mass partitioning in Callistemon plants during drought conditions. Sci. Hortic. 2011, 129, 306-312. [CrossRef]

40. Elansary, H.O.; Salem, M.Z.M. Morphological and physiological responses and drought resistance enhancement of ornamental shrubs by trinexapac-ethyl application. Sci. Hortic. 2015, 189, 1-11. [CrossRef]

41. Toscano, S.; Scuderi, D.; Giuffrida, F.; Romano, D. Responses of Mediterranean ornamental shrubs to drought stress and recovery. Sci. Hortic. 2014, 178, 145-153. [CrossRef]

42. Toscano, S.; Farieri, E.; Ferrante, A.; Romano, D. Physiological and biochemical responses in two ornamental shrubs to drought stress. Front. Plant Sci. 2016, 7, 645. [CrossRef]

43. Sánchez-Blanco, M.J.; Rodriguez, P.; Morales, M.A.; Torrecillas, A. Comparative growth and water relations of Cistus albidus and Cistus monspeliensis plants during water deficit conditions and recovery. Plant Sci. 2002, 162, 107-113. [CrossRef] 
44. Franco, J.A.; Martinéz-Sanchéz, J.J.; Fernández, J.A.; Bañón, S. Selection and nursery production of ornamental plants for landscaping and xerogardening in semi-arid and environments. J. Hortic. Sci. Biotechnol. 2006, 81, 3-17. [CrossRef]

45. Zollinger, N.; Kjelgren, R.; Cerny-Koenig, T.; Kopp, K.; Koenig, R. Drought responses of six ornamental herbaceous perennials. Sci. Hortic. 2006, 109, 267-274. [CrossRef]

46. Mugnai, S.; Ferrante, A.; Petrognani, L.; Serra, G.; Vernieri, P. Stress-induced variation in leaf gas exchange and chlorophyll a fluorescence in Callistemon plants. Res. J. Agric. Biol. Sci. 2009, 4, 913-921.

47. Navarro, A.; Álvarez, S.; Castillo, M.; Bañón, S.; Sánchez-Blanco, M.J. Changes in tissue-water relations, photosynthetic activity, and growth of Myrtus communis plants in response to different conditions of water availability. J. Hortic. Sci. Biotechnol. 2009, 84, 541-547. [CrossRef]

48. Maggio, A.; Raimondi, G.; Martino, A.; De Pascale, S. Salt stress response in tomato beyond the salinity tolerance threshold. Environ. Exp. Bot. 2007, 59, 276-282. [CrossRef]

49. Wu, F.; Bao, W.; Li, F.; Wu, N. Effects of drought stress and N supply on the growth, biomass partitioning and water-use efficiency of Sophora davidii seedlings. Environ. Exp. Bot. 2008, 63, 248-255. [CrossRef]

50. Smirnoff, N. Plant resistance to environmental stress. Curr. Opin. Biotechnol. 1998, 9, 214-219. [CrossRef]

51. Davies, M.J.; Harrison-Murray, R.; Atkinson, C.J.; Grant, O.M. Application of deficit irrigation to container-grown hardy ornamental nursery stock via overhead irrigation, compared to drip irrigation. Agric. Water Manag. 2016, 163, 244-254. [CrossRef]

52. Pollastrini, M.; Desotgiu, R.; Camin, F.; Ziller, L.; Marzuoli, R.; Gerosa, G.; Bussotti, F. Intra-annual pattern of photosynthesis, growth and stable isotope partitioning in a poplar clone subjected to ozone and water stress. Water Air Soil Pollut. 2013, 224, 1761. [CrossRef]

53. Sánchez-Blanco, M.J.; Ortuño, M.F.; Bañon, S.; Álvarez, S. Deficit irrigation as a strategy to control growth in ornamental plants and enhance their ability to adapt to drought conditions. J. Hortic. Sci. Biotechnol. 2019, 94, 137-150. [CrossRef]

54. Aguirrezabal, L.; Bouchier-Combaud, S.; Radziejwoski, A.; Dauzat, M.; Cookson, S.J.; Granier, C. Plasticity to soil water deficit in Arabidopsis thaliana: Dissection of leaf development into underlying growth dynamic and cellular variables reveals invisible phenotypes. Plant Cell Environ. 2006, 29, 2216-2227. [CrossRef]

55. Chaves, M.M.; Flexas, J.; Pinheiro, C. Photosynthesis under drought and salt stress: Regulation mechanisms from whole plant to cell. Ann. Bot. 2009, 103, 551-560. [CrossRef]

56. Osakabe, Y.; Osakabe, K.; Shinozaki, K.; Tran, L.S.P. Response of plants to water stress. Front. Plant Sci. 2014, 5, 86. [CrossRef]

57. Stanton, K.M.; Mickelbart, M.V. Maintenance of water uptake and reduced water loss contribute to water stress tolerance of Spiraea alba Du Roi and Spiraea tomentosa L. Hortic. Res. 2014, 1, 14033. [CrossRef]

58. Waghorn, M.J.; Whitehead, D.; Watt, M.S.; Mason, E.G.; Harrington, J.J. Growth, biomass, leaf area and water-use efficiency of juvenile Pinus radiata in response to water deficits. N. Z. J. For. Sci. 2015, 45, 3. [CrossRef]

59. Santana-Vieira, D.D.S.; Freschi, L.; da Hora Almeida, L.A.; De Moraes, D.H.S.; Neves, D.M.; Dos Santos, L.M.; Bertolde, F.Z.; dos Santos Soares Filho, W.; Coelho Filho, M.A.; da Silva Gesteira, A. Survival strategies of citrus rootstocks subjected to drought. Sci. Rep. 2016, 6, 38775. [CrossRef]

60. Clauw, P.; Coppens, F.; Beuf, K.; Dhondt, S.; Daele, T.V.; Maleux, K.; Storme, V.; Clement, L.; Gonzalez, N.; Inzé, D. Leaf responses to mild drought stress in natural variants of Arabidopsis. Plant Physiol. 2015, 167, 800-816. [CrossRef]

61. da Cunha Cruz, Y.; Scarpa, A.L.M.; Pereira, M.P.; de Castro, E.M.; Pereira, F.J. Growth of Typha domingensis as related to leaf physiological and anatomical modifications under drought conditions. Acta Physiol. Plant. 2019, 41, 64. [CrossRef]

62. Cassaniti, C.; Romano, D.; Hop, M.E.C.M.; Flowers, T.J. Growing floricultural crops with brackish water. Environ. Exp. Bot. 2013, 92, 165-175. [CrossRef]

63. Merwad, A.R.M.; Desoky, E.S.M.; Rady, M.M. Response of water deficit-stressed Vigna unguiculata performances to silicon, proline or methionine foliar application. Sci. Hortic. 2018, 228, 132-144. [CrossRef]

64. Jaleel, C.A.; Sankar, B.; Murali, P.V.; Gomathinayagam, M.; Lakshmanan, G.M.A.; Panneerselvam, R. Water deficit stress effects on reactive oxygen metabolism in Catharanthus roseus: Impacts on ajmalicine accumulation. Colloids Surf. B Biointerfaces 2008, 62, 105-111. [CrossRef] 
65. Kiani, S.P.; Maury, P.; Sarrafi, A.; Grieu, P. QTL analysis of chlorophyll fluorescence parameters in sunflower (Helianthus annuus L.) under well-watered and water-stressed conditions. Plant Sci. 2008, 175, 565-573. [CrossRef]

66. Tahkokorpi, M.; Taulavuori, K.; Laine, K.; Taulavuori, E. After-effects of drought-related winter stress in previous and current year stems of Vaccinium myrtillus L. Environ. Exp. Bot. 2007, 61, 85-93. [CrossRef]

67. Jiang, Y.; Huang, B. Drought and heat stress injury to two cool-season turfgrass in relation to antioxidant metabolism and lipid peroxidation. Crop Sci. 2001, 41, 436-442. [CrossRef]

68. García-Valenzuela, X.; García-Moya, E.; Rascón-Cruz, Q.; Herrera-Estrella, L.; Aguado-Santacruz, G.A. Chlorophyll accumulation is enhanced by osmotic stress in graminaceous chlorophyllic cells. J. Plant Physiol. 2005, 162, 650-661. [CrossRef]

69. Li, S.; Pezeshki, S.R.; Goodwin, S. Effects of soil moisture regimes on photosynthesis and growth in cattail (Typha latifolia). Acta Oecol. 2004, 25, 17-22. [CrossRef]

70. Yamashita, N.; Koike, N.; Ishida, A. Leaf ontogenetic dependence of light acclimation in invasive and native subtropical trees of different successional status. Plant Cell Environ. 2002, 25, 1341-1356. [CrossRef]

71. Souza, P.U.; Lima, L.K.S.; Soares, T.L.; de Jesus, O.N.; Coelho Filho, M.A.; Girardi, E.A. Biometric, physiological and anatomical responses of Passiflora spp. to controlled water deficit. Sci. Hortic. 2018, 229, 77-90. [CrossRef]

72. Guerfel, M.; Baccouri, O.; Boujnah, D.; Chaibi, W.; Zarrouk, M. Impacts of water stress on gas exchange, water relations, chlorophyll content and leaf structure in the two main Tunisian olive (Olea europaea L.) cultivars. Sci. Hortic. 2009, 119, 257-263. [CrossRef]

73. Lee, J.S. The relationship between stomatal opening and photosynthetic activity of the mesophyll in Commelina communis L. J. Environ. Sci. Int. 2006, 15, 1109-1117. [CrossRef]

74. Mathobo, R.; Marais, D.; Steyn, J.M. The effect of drought stress on yield, leaf gaseous exchange and chlorophyll fluorescence of dry beans (Phaseolus vulgaris L.). Agric. Water Manag. 2017, 180, 118-125. [CrossRef]

75. Monclus, R.; Dreyer, E.; Villar, M.; Delmotte, F.M.; Delay, D.; Petit, J.M.; Barbaroux, C.; Le Thiec, D.; Bréchet, C.; Brignolas, F. Impact of drought on productivity and water use efficiency in 29 genotypes of Populus deltoids $\times$ Populus nigra. New Phytol. 2006, 169, 765-777. [CrossRef]

76. Deuner, S.; Zanandrea, I.; Silveira, N.M.; Mesquita, A.C.; Goulart, P.F.P.; Alves, J.D. Stomatal behavior and components of the antioxidative system in coffee plants under water stress. Sci. Agric. 2011, 68, 77-85. [CrossRef]

77. Morales, F.; Abadía, A.; AbadPa, J. Photoinhibition and Photoprotection under Nutrient Deficiencies, Drought and Salinity. In Photoprotection, Photoinhibition, Gene Regulation, and Environment; Advances in Photosynthesis and, Respiration; Demmig-Adams, B., Adams, W.W., Mattoo, A.K., Eds.; Springer: Dordrecht, The Netherlands, 2008; Volume 21, pp. 65-85.

78. Hessini, K.; Ghandour, M.; Albouchi, A.; Soltani, A.; Werner, K.H.; Abdelly, C. Biomass production, photosynthesis, and leaf water relations of Spartina alterniflora under moderate water stress. J. Plant Res. 2008, 121, 311-318. [CrossRef]

79. Ferrar, P.J.; Osmond, C.B. Nitrogen supply as a factor influencing photoinhibition and photosynthetic acclimation after transfer of shade-grown Solanum dulcamara to bright light. Planta 1986, 168, 563-570. [CrossRef]

80. Osmond, C.B.; Anderson, J.M.; Ball, M.C.; Egerton, J.J.G. Compromising efficiency: The molecular ecology of light-resource utilization in plants. In Physiological Plant Ecology; Scholes, J.D., Barker, M.G., Eds.; Blackwell Science: Oxford, UK, 1999.

81. Osmond, C.B. What Is Photoinhibition? Some Insights from Comparisons of Shade and Sun Plants. In Photoinhibition of Photosynthesis-From Molecular Mechanisms to the Field; Baker, N.R., Bowyer, J.R., Eds.; BIOS Scientific Publishers: Oxford, UK, 1994; pp. 1-24.

82. Murata, N.; Takahashi, S.; Nishiyama, Y.; Allakhverdiev, S.I. Photoinhibition of photosystem II under environmental stress. Biochim. Biophys. Acta 2007, 1767, 414-421. [CrossRef]

(C) 2019 by the authors. Licensee MDPI, Basel, Switzerland. This article is an open access article distributed under the terms and conditions of the Creative Commons Attribution (CC BY) license (http://creativecommons.org/licenses/by/4.0/). 